\title{
Article \\ Unlocking the Relationship between Land Finance and Regional Integration
}

\author{
Xinhai Lu ${ }^{1,2,3}$, Mingxu Bai ${ }^{1}$, Bing Kuang ${ }^{2,3, *}$ and Danling Chen ${ }^{4,5}$ \\ 1 College of Public Administration, Huazhong University of Science and Technology, Wuhan 430074, China; \\ xinhailu@hust.edu.cn (X.L.); D201577951@hust.edu.cn (M.B.) \\ 2 College of Public Administration, Central China Normal University, Wuhan 430079, China \\ 3 Institute of Natural Resources Governance, Central China Normal University, Wuhan 430079, China \\ 4 College of Public Administration, Huazhong Agricultural University, Wuhan 430070, China; \\ danlingchen@mail.hzau.edu.cn \\ 5 Institute of Ecological and Environmental Economics, Huazhong Agricultural University, \\ Wuhan 430070, China \\ * Correspondence: kuang117@mail.ccnu.edu.cn
}

Citation: Lu, X.; Bai, M.; Kuang, B.; Chen, D. Unlocking the Relationship between Land Finance and Regional Integration. Land 2021, 10, 895. https://doi.org/10.3390/land10090895

Academic Editor: Luca Salvati

Received: 29 July 2021

Accepted: 22 August 2021

Published: 25 August 2021

Publisher's Note: MDPI stays neutral with regard to jurisdictional claims in published maps and institutional affiliations.

Copyright: (c) 2021 by the authors. Licensee MDPI, Basel, Switzerland. This article is an open access article distributed under the terms and conditions of the Creative Commons Attribution (CC BY) license (https:// creativecommons.org/licenses/by/ $4.0 /)$.

\begin{abstract}
Exploring the relationship between land finance and regional integration is of great significance for optimizing the land management system and promoting high-quality development. Previous studies focused on the impact of land finance on regional development, and rarely concerned the role of regional integration on land revenue. This study reveals the internal association mechanisms between land finance and regional integration, which might provide an integrated theoretical and empirical support for the coordinated development between urban land market and regional economy. We firstly provide a theoretically analytical framework for the relationship between the size of land finance, reliance on land finance, and regional integration, and three hypotheses are proposed. On this basis, an econometric analysis is conducted based on the panel data of the urban agglomerations in the middle reaches of the Yangtze River (UAMRYR) from 2003 to 2016. The results show that an increased amount of land finance revenue promotes the level of regional integration. Specifically, for every $1 \%$ increase in the size of land finance of UAMRYR, Wuhan city-clusters, and Chang-Zhu-Tan city-clusters, the level of regional integration will increase by $0.000040 \%, 0.000021 \%$, and $0.000089 \%$, respectively. Besides, the degree of land finance dependence has a negative impact on the level of regional integration. The threshold regression analysis indicates an inverted U-shaped curve could reflect the relationship between the level of regional integration and the degree of land financial dependence. This study argues that the governments in a particular urban agglomeration should clarify the net effect of the size of land finance and their reliance on land finance, and rationally introducing development strategy according to the synergy between land finance and regional integration.
\end{abstract}

Keywords: size of land finance; reliance on land finance; regional integration; urban agglomerations in the middle reaches of the Yangtze River; China

\section{Introduction}

Land finance, which refers to land-based finance that public land development rights are used as a basis to receive off-budgetary revenue [1,2], has long attracted worldwide attention. The conception is similar, but is more hybrid and complicated than capturing land value, and includes more inclusive forms [3,4]. There are two modes of land finance in China, including land transfer-centered mode and land investment-centered mode [5]. Generally, China is characterized by the latter, as it gained considerably fiscal revenue through sales, leasing, acquisition, and resale of public land. Since the reform of the tax-sharing system in 1994, land finance in China has become the major source in the local fiscal budget [6]. With the development of urbanization and industrialization, the 
size of China's land finance has experienced growth at a rapid and unprecedented rate. It was reported that the revenue from the land conveyance in China reached 59.58 and 3646.17 billion Yuan in 2003 and 2016, accounting for $9.30 \%$ and $42.38 \%$ of local government revenue, respectively [7]. This fiscal effect is mainly derived from collecting revenue through land conveyance by transferring state-owned land use rights to private-owned for a fixed period [8]. As its prominent role in local fiscal revenue, the historical evolution, primary causes and outcomes, and bidirectional influence of land finance have been widely discussed [9-11].

Notably, several studies have also highlighted the potential effects of land finance on regional development [12-14]. Studies directly or indirectly related to the impacts of land finance on regional development by economists, sociologists, and urban studies researchers are broad, but scattered. Some have focused on the positive or negative roles of land finance on regional economic growth from a macro perspective $[11,15,16]$. Land finance interferes with regional development through pathways, such as urbanization and industrial policies [17], improvement of urban-rural infrastructure [18], industrial development interventions [19], and other open space needs [20]. Others have assessed the impact of land finance on regional development at a micro-level [21,22]. An econometric approach is often used to describe their mutual relationship. Moreover, the vital role of land finance impacting regional integration through intermediate variables, such as infrastructure construction, land urbanization, and other regional development indices, were confirmed from a side [14]. As some argued, land finance is a tool to create revenue or achieve political promotion $[23,24]$. On the one hand, land finance is likely to affect regional spatial development because of its connectivity in infrastructure urbanization [2] Moreover, a few empirical studies considered that improving regional development can affect production efficiency and factor prices, and in turn, causing further increases in the size of land finance [11,25]. On the other hand, land finance has grown in its importance to enhance the socio-economic adjustment and reconstruction across regions. However, the experiences in developing countries have generated a good amount literature that capture the opposite [26,27]. From the perspective of revenue-generating, it has been criticized that land finance competition enlarges regional disparities between the developed and the poor areas. This contributes to a more unbalanced distribution of social and economic factors, leading to polarization [25].

To ensure sustainable regional development, continuous attention has been paid to regional integration development by China's central government [14]. China has launched a series of spatial development strategies and policies to concentrate future development in economic zones, or city-clusters in recent years [28]. Land finance, along with other financial resources, serves as the material basis to achieve this goal. Previous studies of regional integration have summarized the following factors that particularly influenced its development. The first is political factors, with local governments tending to seek regional integration for common interests $[29,30]$. The second is national strategies or regional development planning [31,32]. "Regional-biased" development strategies, such as integration of the Yangtze River Delta region, the construction of the Yangtze River Economic Belt, have largely raised the superiority of particular areas in the competition of cross-regional or intra-regional integration. Thirdly, the financial situation of local government is a key factor affecting the process of regional integration [33]. The government's financial pressure largely limits the development of regional integration, and a huge fiscal gap lags the inter-regional cooperation and transformation of local government functions.

Previous studies focused on the impact of land finance on regional growth and productivity, while less attention has been devoted to the mutual relationship between land finance and regional integration. Given the crucial role of land resources in sustaining economic growth and the feedback force of regional development on land finance, the linkage of land finance and regional integration needs more concerns.

An urban agglomeration is the highest form of spatial organization in the mature stage of urban development and plays an important role in the process of regional integration, 
particularly for developing countries. It also serves as a primary carrier for countries and regions to participate and compete on the international stage. Since the 1990s, China's urban agglomerations have rapidly developed and gradually become the most important form of regional integration. As one of the national urban agglomerations, the urban agglomeration in the middle reaches of the Yangtze River (UAMRYR) is a key area connecting the East and the West of China. It is expected to continue being at the forefront of economic development and promote regional coordinated development in China. Thus, this study unlocks the linkage between land finance and regional integration, using data of UAMRYR China for the period 2003-2016. The core issues are as follows. Does land finance promote regional integration or promote polarization? And in turn, does regional integration increase or hinder land finance? This study contributes to the existing literature in the following two aspects. First, we propose an analytical framework for exploring the bi-directional relationship between land finance and regional integration, and is among the first to empirically investigate such relations. Second, the impacts of regional integration on land revenue are examined under a threshold econometric framework in this study. Due to the economy and diseconomy of agglomeration, there could be a significant nonlinear influence of regional integration on land finance, which is not captured by previous studies.

This paper is organized into five parts. After the introduction, Section 2 builds an analytical framework to analyze the internal relationship between land finance and regional integration, and proposes our hypothesis. Section 3 focuses on case description, variables selection, methodology, and data sources. Section 4 shows the results and discusses the questions we proposed. Conclusions are provided in Section 5.

\section{Theoretical Analysis and Hypothesis}

Theoretically, capital is commonly viewed as a fundamental factor in achieving regional cohesion [29-31]. This largely attributes to its important role in the reduction of regional economic, and social disparities, and enhancement of local governments' cooperation $[32,33]$.

\subsection{Size of Land Finance Affecting Regional Integration}

Regional integration is a complex and systematic concept, including economic, market, and spatial [14]. The impacts of land finance on regional integration, thus, be widely and dispersed. Being largely affected by the self-sufficiency strategy of Maoists, all regions in China have emphasized development with their own production and resources. Naturally, land finance can provide material support for the development of these resources, production, and factor markets, thereby accelerating the process of regional development. In this way, areas with higher land revenue often have the stronger financial capacity to promote the level of regional integration [34]. In turn, improving the level of regional integration causes an increase in land value, which could be captured and integrated into the local financial system. Moreover, local protectionism should be the primary incentive for regional segmentation under the co-pressure of GDP growth and political promotion [11]. However, to get a higher amount of land revenue, the government tends to attract investment by flexibly using beggar-thy-neighbor policies and reducing market barriers [35]. As a result, different regions in China are more integrated, due to a decreased magnitude of market segmentation. Moreover, land finance has similar spatial interaction characteristics with other economic behaviors, which leads to a general rise in housing prices [36]. As a decentralized power in market mechanisms, housing prices have been confirmed to induce labor mobility by a large number of empirical studies [36,37]. In the process of increasing the size of land finance, industrial spatial agglomeration or industrial transfer closely related to urban agglomeration will occur because of the liquidity costs between different regions. As argued above, the impact of land finance on regional integration is mainly for the following two aspects. Firstly, part of the revenue from land conveyance becomes the construction capital in the process of integration. Secondly, it can indirectly support integration by reducing costs. Thus, this study proposes the first hypothesis: 
Hypothesis 1 (H1). An increased amount of revenue from land finance leads to an increase in the level of regional integration.

\subsection{Reliance on Land Finance Affecting Regional Integration}

Heavy reliance on land revenue is unsustainable and unwise for the long term [2], which could then bring a negative influence on regional integration. A greater dependence on land revenues indicates our governments have difficulty getting revenue from other economic sources. Due to the dependence on land finance, local governments have the incentive to keep the scarce raw materials and prevent the inflow of goods produced in other areas. This aggravates the division of regional markets and space [14]. With the increasing dependence on land finance, the path dependence of the unbalanced distribution of land interests has been further strengthened. This development mode has an important impact on the unbalanced socio-economic development in China. On the one hand, farmer's poverty caused by the unfair distribution of land expropriation benefits will have a greater influence on regional segmentation. On the other hand, the dependence on land finance has aggravated the imbalance of rent-seeking and wealth distribution [38]. Moreover, in terms of efficiency of revenue-generating, the efficiency of reliance on land finance in the developed areas is higher than that in the less developed areas. In this case, central governments could be lured to allocating more public investment to developed sectors. This biased development also happens between the countryside and the city [39]. Thus, the second hypothesis is proposed as follow:

Hypothesis 2 (H2). An increased degree of land finance revenue dependence leads to a decrease in the level of regional integration.

\subsection{Regional Integration and Its Linkage with Reliance on Land Finance}

China's regional integration strategy is mainly based on cross-regional resource integration, free flow of production factors, and government cooperation [31,32]. This process will inevitably affect the local governments' intention to seek land finance, due to huge land capitalization benefits. At the early stage of regional integration, governments are mostly focusing on the horizontal competition of regional economies. To increase tax revenue and stimulate economic development, governments tend to increase the scale of urban land, and sell industrial land at a low price through their monopoly position [40]. In a short time, the new round of urban land expansion caused by regional integration creates objective conditions for administrative departments to obtain land financial revenue. On this basis, a greater impact on the original fiscal and taxation balance system has termed, and thus, aggravated the degree of land financial dependence. Governments at different levels embedding themselves in the financial expenditure competition of public services, social security, and infrastructure with gradual change of political assessment system. This will undoubtedly exacerbate the fiscal gap [33]. In the long period, regional integration based on economic linkages and regional cooperation has a complete self-financing mechanism [14]. The circulation of this mechanism can make up for the capital gap formed by supporting the supply of urban infrastructure, and promote the selective geographical agglomeration of capital, labor, and technology. Both could generate a huge tax creation effect and weakening the government's willingness to accumulate land finance. Moreover, spatial agglomeration of industries, results in a decreased demand for new-added construction land [41]. Furthermore, the mode of "yidi shengcai" has been gradually replaced by other budgetary revenue through great development of the tertiary industry [42]. As a result, the degree of reliance on land finance began to decrease. Accordingly, we formulated the third hypothesis:

Hypothesis 3 (H3). There is an inverted $U$-shaped relationship between regional integration and land financial dependence. 


\section{Methodology and Data}

\subsection{Study Area}

The UAMRYR is located at $110^{\circ} 23^{\prime}-118^{\circ} 28^{\prime} \mathrm{E}$ longitude and $26^{\circ} 29^{\prime}-31^{\circ} 51^{\prime} \mathrm{N}$ latitude and covers $326,100 \mathrm{~km}^{2}$. The UAMRYR comprises three national-level city-clusters, namely, Wuhan city-clusters, Chang-Zhu-Tan city-clusters, and Poyang Lake city-clusters (Figure 1), and plays an important role in linking the eastern-western areas and connecting the southnorth regions. In 2017, UAMRYR generated $9.6 \%$ of China's gross domestic product by $3.4 \%$ of the total area of China and $9.0 \%$ of the country's population. With the further implementation of "Development Planning for City Groups in the Middle Reaches of the Yangtze River", UAMRYR has responded positively to national, regional integration policies and made substantial progress. However, such great economic growth has been accelerated under an unreasonable expansion of land finance. According to the data of China Urban Statistics Yearbook, land conveyance revenue in UAMRYR has expanded by 2.5 times between 2003 and 2016, and the proportion of land finance to local fiscal budgetary receipts has increased by 1.48 times. The rapid expansion of land finance was mainly generated from the occupation of farmland and other rural areas. Thus, how to accelerate the development of regional integration and reshape sustainable financial growth mechanism in UAMRYR has become a key problem need to be solved urgently. The analysis based on the UAMRYR is relevant for other regions which are confronted with land constraints during industrialization and urbanization, and highlights the necessity to coordinate regional governance policies with land finance policies.

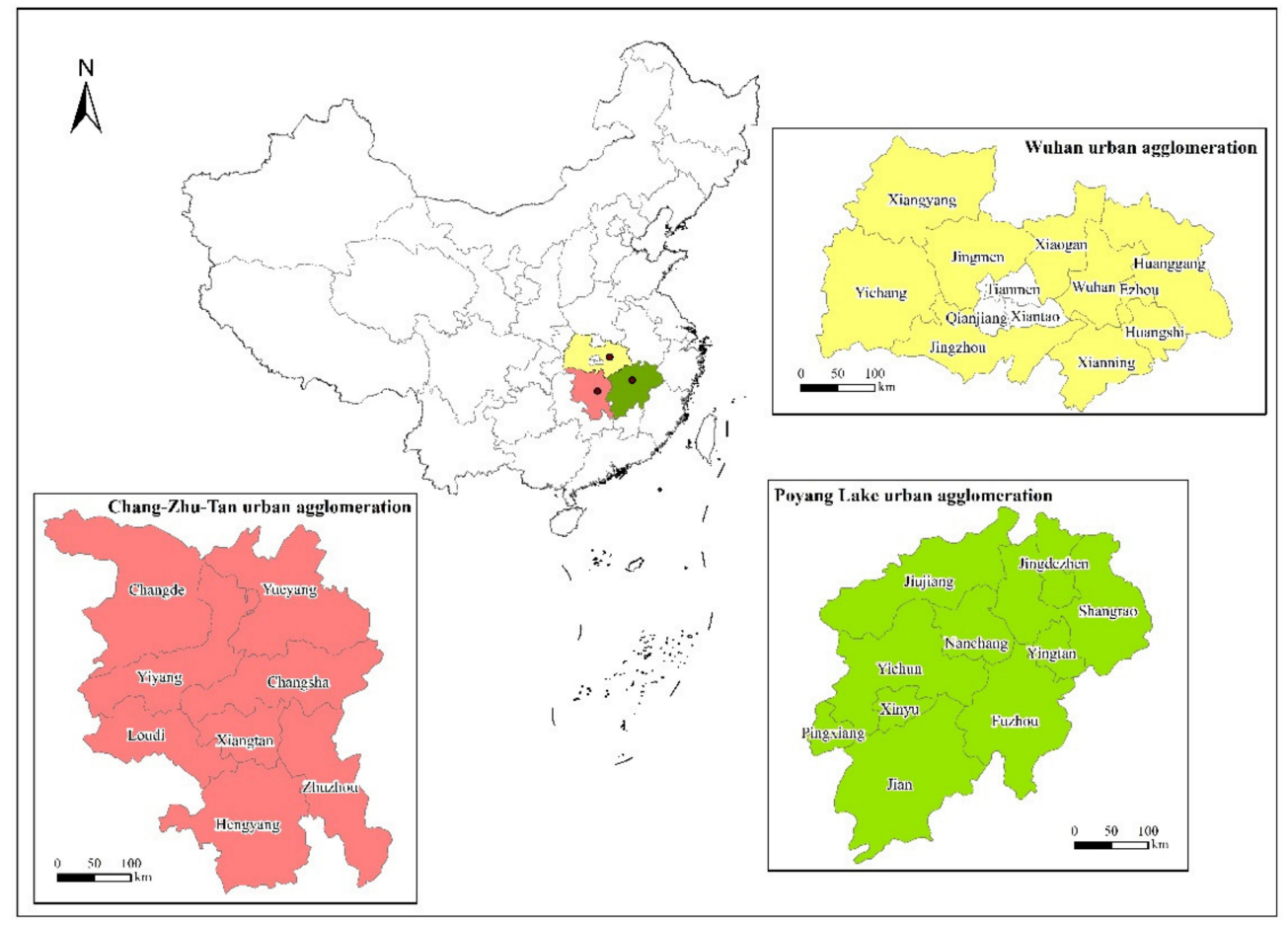

Figure 1. The geographic location of UAMRYR.

\subsection{Variables Measurement}

\subsubsection{Land Finance}

There are two interpretations of land finance in academia [5]. In a narrow sense, land finance refers to the revenue from the land conveyance. By comparison, generalized land finance refers to all the public revenue that local governments obtain through land and real estate. However, revenue directly and indirectly related to land and real estate is complicated, which brings difficulties to acquiring research data. Meanwhile, revenue from land conveyance accounts for a large proportion of the entire fiscal system, which can better reflect the land financing behavior of local governments. Therefore, this study selects 
the revenue from land conveyance as the measurement index of land finance. Land finance is generally reflected in two ways, namely, the amount of land revenue and the degree of reliance on land finance. In terms of amount in this study, the annual revenue from land conveyance (landreve) is adopted, which is an indicator that has been widely used in the existing literature. This is used to verify Hypothesis 1. Moreover, the proportion of annual revenue from land conveyance on fiscal budgetary revenue is utilized to reflect the degree of reliance on land finance [14,25], coded with Landreliance. The variable Landreliance is used to test Hypotheses 2 and 3.

\subsubsection{Regional Integration}

Another key variable in our study is regional integration (RI). Academics have long paid attention to regional integration, and formed research teams to focus on "new regionalism" and "multi-centralism" [29,30]. Regional integration is characterized by complexity and diversity-many scholars constructed measurement systems from the perspective of trade, population mobility, and other indicators [31-33]. As a result, existing measurement systems and indices have various discrepancies, and sometimes presents contradictory. Fortunately, the law of purchasing power parity (PPP) suggested by Parsley and Wei [43] provides us a better idea to understand this variable. In this law, if the dispersion of price differentials between regions is small, we believe that the region is more integrated with others-otherwise, the region is less integrated with others. This supports the conclusion that regional integration reflects the extent of regional price differentials, and the process of its growth and development is related to the cross-regional flow of goods and services. Following this way, an effective model was used to investigate regional integration through the cross-regional dispersion of price differences [44].

Firstly, supposing that $p_{i t}^{k}$ and $p_{j t}^{k}$ is the price of good $k$ in the region $i$ and $j$ at time $t$. When the arbitrage mechanism works properly, the price difference between regions $i$ and $j$ can be expressed as:

$$
Q_{i, j t}^{k}=\operatorname{In} p_{i}^{k}-\operatorname{In} p_{j}^{k}
$$

Secondly, the absolute change of price differentials can be calculated by Equation (2):

$$
\Delta Q_{i, j t}^{k}=\operatorname{In}\left(p_{i t}^{k} / p_{j t}^{k}\right)-\operatorname{In}\left(p_{i t-1}^{k} / p_{j t-1}^{k}\right)=\operatorname{In}\left(p_{i t}^{k} / p_{i t-1}^{k}\right)-\operatorname{In}\left(p_{j t}^{k} / p_{j t-1}^{k}\right)
$$

Notably, since bilateral price differentials measured by $Q_{i, j t}^{k}$ and $Q_{j, i t}^{k}$ should be equivalent, we used the absolute value of $Q_{i, j t}^{k}\left(\left|Q_{i, j t}^{k}\right|\right)$ to evaluate the price dispersion. According to previous studies, $\left|Q_{i, j t}^{k}\right|$ mainly originated from two parts. The first is good-specific heterogeneity measured by $a^{k}$, and the second is price dispersion caused by region segmentation, which is measured by $\varepsilon_{i, j t}^{k}$. Without filtering the effect of the first part, the level of regional integration would be underestimated. Hence, when measuring variability $q_{i, j t}^{k}$, we remove the good-specific effect by using de-mean method:

$$
q_{i, j t}^{k}=\left|\Delta Q_{i, j t}^{k}\right|-\left|\Delta \bar{Q}_{t}^{k}\right|=\left(a^{k}-a^{-k}\right)+\left(\varepsilon_{i, j t}^{k}-\bar{\varepsilon}_{i, j t}^{k}\right)
$$

Next, we obtain the index for regional segmentation by merging the price variability in each region calculated by Equation (4) (where $\mathrm{N}$ represents the number of cities in a particular region).

$$
\operatorname{Var}\left(q_{i t}\right)=\sum_{i \neq j}\left(q_{i t}\right) / N
$$

Finally, we constructed the index of regional integration.

$$
R I_{i t}=\sqrt{\frac{1}{\operatorname{Var}\left(q_{i t}\right)}}
$$




\subsubsection{Control Variables}

The level of regional integration is affected by many other factors. This study selected a series of possible influencing factors as control variables.

1. Market size: On the one hand, a larger market size indicates more firms competing in a parallel market, and then increase the flow density of goods and productive factors. On the other hand, the increase of market size will promote division of refined labor, and enable local enterprises to form higher-level competitiveness. Both impacts weaken the motivation of local protectionism. According to the previous literature [45], this study uses economic density (ED) and total population (RK) to characterize market size.

2. Transportation accessibility: Distance is the natural factor affecting market segmentation. In theory, improving roads and other transportation infrastructure will facilitate the flow of production factors between regions and optimize the allocation of resources. Transportation accessibility will increase the level of regional integration mainly by overcoming space distance obstacles for commodity circulation. In recent years, the high-speed railway in UAMRYR has developed rapidly, and the construction of road infrastructure between cities has been greatly improved. According to the previous literature [46], we use per capita highway mileage (TR) and per capita business total of posts and telecommunications (TE) in each region to characterize the variable "transportation accessibility".

3. Ownership: The higher the proportion of the state-owned economy, the stronger the motivation of local government to divide the market. Therefore, it is necessary to control the influence of ownership structure. Following the existing literature [47], the proportion of employment in state-owned enterprises in the total employment is used to measure ownership (OW).

4. Fiscal decentralization: China's fiscal decentralization system constitutes the motive for local protection and market segmentation. A higher level of fiscal decentralization stimulated local governments to protect local economies and industries, which cause the distortions of resource allocation and market segmentation. Drawing on previous studies [48], this study uses the percentage of per capita fiscal expenditure in the local budget in per capita fiscal expenditure in the central budget to characterize the degree of fiscal decentralization (FI).

5. International openness: International openness is beneficial for regional integration by influencing local culture and governance concepts. As a result, the government's incentive to control the internal market has weakened. In general, there are two aspects of international openness, one is trade openness (TA), and the second is foreign direct investment (FDI). According to the previous literature [49], we use the proportion of the total amount of import and export in GDP to reflect the level of trade openness, and the proportion of FDI in GDP to characterize the situation of FDI.

6. Financial crisis: Referring to the existing literature [50], some special events or policies also affect regional integration. During the period studied, the major impact of the financial crisis in 2008 could not be ignored. We further set the value of the dummy variable Crisis (CR) from 2003 to 2008 as 0, and the value of 2009 to 2016 as 1.

\subsection{Models Setting}

The first basic equation for the size of land finance affecting regional integration is:

$$
R I_{i t}=\alpha_{1}+\beta_{1} \text { Landreve }_{i t}+\beta_{k} X_{k i t}+\varepsilon_{i t}+v_{i t}
$$

where, $R I_{i t}$, Landreve $i t$ denote as regional integration and the size of land finance, respectively, $\alpha_{1}$ is the coefficient of Landreve $i_{i t}, X_{k i t}$ is the vector of the other $k$ control variables, $\beta_{k}$ are their coefficients, $\alpha_{0}$ is the intercept term, $\varepsilon_{i t}$ represents the stochastic error term, and $v_{i t}$ represents the individual industrial effect. 
The second basic equation for reliance on land finance affecting regional integration is:

$$
R I_{i t}=\alpha_{1}+\beta_{1} \text { Landreliance }_{i t}+\beta_{k} X_{k i t}+\varepsilon_{i t}+v_{i t}
$$

The meaning of the corresponding variables is consistent with Equation (6), Landreliance ${ }_{i t}$ is the reliance on land finance.

According to the above analysis, regional integration and reliance on land finance have a nonlinear relationship. Thus, we further proposed a threshold regression model as follow:

$$
\begin{aligned}
& \text { Landreliance }_{i t}=\alpha_{1}+\beta_{11} M I_{i t} \times d\left(q \leq \lambda_{1 i}\right)+\beta_{12} M I_{i t} \times d\left(\lambda_{1 i} \prec q \leq \lambda_{2 i}\right)+\cdots \beta_{1 n-1} M I_{i t} \\
& \times d\left(\lambda_{n-1 i} \prec q \leq \lambda_{n i}\right)+\beta_{k} X_{k i t}+\varepsilon_{i t}+v_{i t}
\end{aligned}
$$

Here, the meaning of the corresponding variables is consistent with Equation $(7), d\left({ }^{*}\right)$ is an indicative function. When the condition in parentheses is net, the value is 0 , and otherwise, the value is 1. $q$ is the threshold variable, $\lambda$ is the threshold value.

\subsection{Data Sources}

Due to the availability of statistics, in this paper, we used the panel data of 28 cities in UAMRYR from 2003 to 2016. The original data were derived from China City Statistical Yearbook, and China Land and Resources Statistical Yearbook. To eliminate the impact of price fluctuations, this study used the GDP index and consumer price index to adjust corresponding variables to comparable prices. The base period is 2003. Moreover, to eliminate the dimension and magnitude difference of the original data, we normalized the original data by the software Stata13.0. Table 1 describes the indicators we selected.

Table 1. Summary statistics of the variables.

\begin{tabular}{cccccc}
\hline Variable & N & Minimum & Maximum & Mean & Std. Deviation \\
\hline Landreve & 392 & $80,402.360000$ & $1,393,296.000000$ & $524,321.772381$ & $390,233.299266$ \\
\hline Landreliance & 392 & 0.228905 & 0.871395 & 0.608041 & 0.144196 \\
\hline RI & 392 & 2.00143 & 10.0116 & 6.2721162 & 2.019137 \\
\hline ED & 392 & 0.661251 & 4.38744 & 1.936025 & 0.952409 \\
\hline RK & 392 & 3474.58 & 4637 & 4174.2212 & 350.4962 \\
\hline TR & 392 & 0.43884 & 1.33029 & 0.9175608 & 0.307648 \\
\hline TE & 392 & 9.17675 & 65.04032 & 25.651602 & 12.14869 \\
\hline OW & 392 & 0.28952 & 0.781077 & 0.5498839 & 0.132693 \\
\hline FI & 392 & 0.010315 & 0.084609 & 0.0419804 & 0.020589 \\
\hline TA & 392 & 0.063833 & 0.181023 & 0.1080147 & 0.033387 \\
\hline FDI & 392 & 0.011966 & 0.044422 & 0.0198195 & 0.007055 \\
\hline CR & 392 & 0 & 1 & - & \\
\hline
\end{tabular}

\section{Results and Discussion}

\subsection{Land Revenue Size, Land Revenue Dependence, and Regional Integration}

Table 2 provided the estimated results with Landreve as the dependent variable. Models I to IV are based on the data of UAMRYR, Wuhan city-clusters, Chang-Zhu-Tan cityclusters, and Poyang Lake city-clusters, respectively. In Models I, II, and III, the regression coefficients of Landreve are 0.000040, 0.000021, and 0.000089, respectively. All of them have passed the significance tests. This indicates that for every $1 \%$ increase in the size of land finance of URMRYR, Wuhan city-clusters, and Chang-Zhu-Tan city-clusters, the level of regional integration will increase by $0.000040 \%, 0.000021 \%$, and $0.000089 \%$, respectively. These are consistent with Hypothesis 1 . The regression coefficient of the Poyang Lake city-cluster (Model IV) also shows that the size of land finance has a positive effect on regional integration, while it failed in the significance test. 
Table 2. Estimated results for Landreve as the dependent variable.

\begin{tabular}{|c|c|c|c|c|}
\hline \multirow{2}{*}{$\begin{array}{c}\text { Dependent Variable } \\
\text { Independent Variables }\end{array}$} & \multicolumn{4}{|c|}{ RI Index } \\
\hline & Model I & Model II & Model III & Model IV \\
\hline Region & UAMRYR & $\begin{array}{c}\text { Wuhan } \\
\text { city-clusters }\end{array}$ & $\begin{array}{l}\text { Chang-Zhu-Tan } \\
\text { city-clusters }\end{array}$ & $\begin{array}{l}\text { Poyang Lake } \\
\text { city-clusters }\end{array}$ \\
\hline Landreve & $\begin{array}{l}0.000040 * \\
(0.000022)\end{array}$ & $\begin{array}{c}0.000021 \text { **** } \\
(0.000008)\end{array}$ & $\begin{array}{c}0.000089^{* * * *} \\
(0.000033)\end{array}$ & $\begin{array}{c}0.000018 \\
(0.039500) \\
\end{array}$ \\
\hline ED & $\begin{array}{c}0.080324^{* * *} \\
(0.016391)\end{array}$ & $\begin{array}{c}0.1068177^{* * *} \\
(0.021084)\end{array}$ & $\begin{array}{c}-0.0538737 * * \\
(0.0243467)\end{array}$ & $\begin{array}{c}0.6598206^{* * *} \\
(0.065254)\end{array}$ \\
\hline RK & $\begin{array}{c}0.0000871 \text { ** } \\
(0.000061)\end{array}$ & $\begin{array}{c}-0.0003546^{* * *} \\
(0.000078)\end{array}$ & $\begin{array}{l}0.0001732 * \\
(0.000090)\end{array}$ & $\begin{array}{c}0.0004212^{* * *} \\
(0.000050)\end{array}$ \\
\hline TR & $\begin{array}{c}0.033107 \\
(0.021557) \\
\end{array}$ & $\begin{array}{c}0.041950 \\
(0.027729) \\
\end{array}$ & $\begin{array}{c}0.004014 \\
(0.032020) \\
\end{array}$ & $\begin{array}{c}-0.031354 * \\
(0.017030)\end{array}$ \\
\hline TE & $\begin{array}{l}0.001044 * * \\
(0.000437)\end{array}$ & $\begin{array}{c}-0.001158^{* *} \\
(0.000563)\end{array}$ & $\begin{array}{c}0.004283^{* * * *} \\
(0.000650)\end{array}$ & $\begin{array}{l}0.000895^{*} \\
(0.000457)\end{array}$ \\
\hline OW & $\begin{array}{c}0.000459 \\
(0.040771)\end{array}$ & $\begin{array}{l}-0.014226 \\
(0.052444)\end{array}$ & $\begin{array}{l}-0.050735 \\
(0.060558)\end{array}$ & $\begin{array}{l}0.016013^{*} \\
(0.008401)\end{array}$ \\
\hline FI & $\begin{array}{l}-0.159911 \\
(0.994430) \\
\end{array}$ & $\begin{array}{l}-2.026822 \text { ** } \\
(-1.005914) \\
\end{array}$ & $\begin{array}{l}2.312788^{* *} \\
(1.077067) \\
\end{array}$ & $\begin{array}{l}-0.508969 \\
(0.780843) \\
\end{array}$ \\
\hline TA & $\begin{array}{l}0.243436^{* *} \\
(0.134683)\end{array}$ & $\begin{array}{c}0.085804 \\
(0.173244)\end{array}$ & $\begin{array}{c}-0.650638^{* * *} \\
(0.200050)\end{array}$ & $\begin{array}{l}0.051132 * \\
(0.071800)\end{array}$ \\
\hline FDI & $\begin{array}{c}0.620479 \\
(0.821217)\end{array}$ & $\begin{array}{l}-2.779955 * * \\
(1.056338)\end{array}$ & $\begin{array}{c}3.637680 * * * \\
(1.219786)\end{array}$ & $\begin{array}{l}1.173581 * \\
(0.660414)\end{array}$ \\
\hline CR & $\begin{array}{c}-0.016769 * \\
(0.009974)\end{array}$ & $\begin{array}{l}-0.005533 \\
(0.012830)\end{array}$ & $\begin{array}{c}-0.011573 \text { ** } \\
(0.004815)\end{array}$ & $\begin{array}{l}-0.009867 \\
(0.007899)\end{array}$ \\
\hline Constant & $\begin{array}{l}-0.276990 \\
(0.212232)\end{array}$ & $\begin{array}{c}1.537116^{* * *} \\
(0.272996)\end{array}$ & $\begin{array}{c}-0.7012253 * * \\
(0.315237)\end{array}$ & $\begin{array}{c}-1.718702 * * * \\
(0.177553)\end{array}$ \\
\hline $\mathrm{R}^{2}$ : overall & 0.8812 & 0.0437 & 0.4537 & 0.9681 \\
\hline $\mathrm{F}$ & $165.7400^{* * *}$ & $33.2700^{* * *}$ & $28.4900 * * *$ & $11.9000^{* * *}$ \\
\hline Hausman test chi ${ }^{2}$ & $\mathrm{FE}$ & FE & FE & $\mathrm{FE}$ \\
\hline
\end{tabular}

Note: Standard errors are included in parentheses. ${ }^{*},{ }^{* *},{ }^{* * *}$ represent $10 \%, 5 \%, 1 \%$ statistical level respectively, FE denotes fixed-effects and random-effects estimates.

In terms of the estimated results of the control variables in Table 2. (1) Market size. In Models I, II, and IV, the estimated values of variable economic density are 0.080324 , 0.1068177 , and 0.6598206 , respectively, and all have passed the $1 \%$ significance level hypothesis test. While Model III is significantly negative. According to the Growth Pole Theory [51], economic growth did not occur in all places and sectors at the same time. Thus, the impact on the progress of integration in different regions might also be different. In Models I, III, and IV, the coefficient of the variable total population is significantly positive, which means in UAMRYR, Chang-Zhu-Tan city-clusters, and Poyang Lake city-clusters, population growth contributes to regional integration. The result of Model II is on the contrary. Although population growth can provide labor resources for regional economic development, it can also aggravate the imbalance of regional development in certain areas [14]. This is not conducive to the process of regional integration. (2) Transportation accessibility. In Models I, II, and III, the coefficients of variable per capita highway mileage are all positive, while they are not statistically significant. Per capita highway mileage is an important factor affecting the cost of commuting mobility. However, the potential transportation services in the UAMRYR have not been fully tapped [31]. In Model IV, the effective coefficient of per capita highway mileage on regional integration is -0.031354 . Posts and telecommunications, an important indicator reflecting the level of urban infrastructure [46], are also important factors affecting the process of regional integration. Apart from Model II, the estimated values of the variable per capita business total of posts and telecommunications in the other three models are all significantly positive, which means that the growth of posts and telecommunications services will promote the level of regional 
integration. (3) Ownership. The estimation results of Models I, II, and III are not statistically significant. In Model IV, the correlation coefficient of variable ownership is 0.016013 , and it has passed the $10 \%$ significance level test. This is consistent with the previous theoretical analysis, which means that the proportion of state-owned economies had a significantly positive linear relationship to regional integration. (4) Fiscal decentralization. The coefficients of Model I and Model II were -0.159911 and -0.508969 , respectively, and none of them passed the significance test. Both Models II and III are statistically significant, but the direction of the regression coefficients is exactly the opposite. Fiscal decentralization will enable local governments to implement market segmentation policies, and the incentives for segmentation under different economic development levels are different [9], which directly affects the impact direction and extent of fiscal decentralization on regional integration. (5) International openness. Foreign trade and investment are important ways to promote the upgrading of local industrial structures. The rationalization and advancement of the industrial structure are important signs of regional integration [49]. Different regions have different capabilities of foreign trade and investment, and their impacts on regional integration are also different. From the regression results of variables trade and FDI, there are obvious differences in the signs and significant characteristics of the coefficients in different models. (6) Financial crisis. In the four models, the estimated values of this variable are $-0.016769,-0.005522,-0.011573$, and -0.009867 , respectively. However, only Model I and Model III are statistically significant. The financial crisis will have a strong negative impact on regional trade and investment, industrial structure, and employment [50], which will be further transmitted to the level of regional integration.

Table 3 provided the estimation results with Landreliance as the dependent variable. Models V-VIII are based on the data of UAMRYR, Wuhan city-clusters, Chang-Zhu-Tan city-clusters, and Poyang Lake city-clusters, respectively. The coefficient of Landreliance is -2.561663 , in Model V, and -0.3000881, $-0.0571162,-1.579270$ in Model VI, VII, and VIII, respectively. This finding indicated that a $1 \%$ increase in the proportion of land conveyance income led to a $2.561663 \%$ decrease in the level of regional integration. By contrast, except for Chang-Zhu-Tan city-clusters, this result is still valid at least 10 percent-level after holding all other variables unchangeable. The estimated coefficient of Landreliance affirms Hypothesis 2, in that an increase in the degree of land finance dependence is associated directly with a decrease in the level of regional integration. Similar to the regression results with Landreve as the dependent variable, in different research samples, the influence direction of each control variable on regional integration and its statistical significance is also different. Variables ED, RK, TE, and TA have a significantly positive effect on regional integration, while CR has hindered regional integration. Besides, fiscal decentralization is negatively correlated with regional integration, but not statistically significant. For every $1 \%$ increase in FDI, the level of regional integration will increase by $0.620479 \%$.

Table 3. Estimated results for Landreliance as the dependent variable.

\begin{tabular}{ccccc}
\hline Dependent Variable & \multicolumn{3}{c}{ RI Index } \\
\hline Independent Variables & Model V & Model VI & Model VII & Model VIII \\
\hline Region & UAMRYR & $\begin{array}{c}\text { Wuhan } \\
\text { city-clusters }\end{array}$ & $\begin{array}{c}\text { Chang-Zhu-Tan } \\
\text { city-clusters }\end{array}$ & $\begin{array}{c}\text { Poyang Lake } \\
\text { city-clusters }\end{array}$ \\
\hline \multirow{2}{*}{ Landreliance } & $-2.561663^{* * *}$ & $-0.300088^{* *}$ & -0.057116 & $-1.579270^{*}$ \\
& $(0.504922)$ & $(0.148185)$ & $(0.0615515)$ & $(0.822385)$ \\
\hline ED & 1.425773 & 0.165658 & $-0.071837^{* *}$ & $0.878289^{*}$ \\
& $(2.176658)$ & $(1.345300)$ & $(0.032456)$ & $(0.522881)$ \\
\hline \multirow{2}{*}{ RK } & $-0.004446^{* *}$ & 0.000418 & $0.000119 * *$ & $-0.009712^{* * *}$ \\
TR & $(0.002012)$ & $(0.001244)$ & $(0.000048)$ & $(0.001223)$ \\
\hline
\end{tabular}


Table 3. Cont.

\begin{tabular}{|c|c|c|c|c|}
\hline \multirow{2}{*}{$\begin{array}{c}\text { Dependent Variable } \\
\text { Independent Variables }\end{array}$} & \multicolumn{4}{|c|}{ RI Index } \\
\hline & Model V & Model VI & Model VII & Model VIII \\
\hline $\mathrm{TE}$ & $\begin{array}{c}-0.092259 * \\
(0.049146)\end{array}$ & $\begin{array}{c}-0.090434 * * * \\
(0.030372)\end{array}$ & $\begin{array}{c}0.006795^{* * *} \\
(0.001181)\end{array}$ & $\begin{array}{c}0.015962 \\
(0.029866)\end{array}$ \\
\hline OW & $\begin{array}{c}-19.367990 \text { *** } \\
(5.209882)\end{array}$ & $\begin{array}{c}-3.409640 * \\
(2.020006)\end{array}$ & $\begin{array}{l}-0.070219 \\
(0.128616)\end{array}$ & $\begin{array}{c}-6.500069 \text { ** } \\
(3.166346)\end{array}$ \\
\hline FI & $\begin{array}{c}-68.190700 \\
(123.130300)\end{array}$ & $\begin{array}{c}151.883300 * * \\
(76.101580)\end{array}$ & $\begin{array}{l}-1.586178 \\
(2.989006)\end{array}$ & $\begin{array}{l}-75.150440 \\
(74.833380)\end{array}$ \\
\hline TA & $\begin{array}{c}-0.973132 \\
(12.221640)\end{array}$ & $\begin{array}{c}17.575320 * * * \\
(7.553675)\end{array}$ & $\begin{array}{c}-1.569395^{* * *} \\
(0.295923)\end{array}$ & $\begin{array}{c}3.518452 \\
(7.427796)\end{array}$ \\
\hline FDI & $\begin{array}{c}-120.682700 * * \\
(57.356950)\end{array}$ & $\begin{array}{c}152.932100 * * * \\
(35.449890)\end{array}$ & $\begin{array}{c}-5.5518920 * * * \\
(1.381510)\end{array}$ & $\begin{array}{c}8.042059 \\
(34.859130)\end{array}$ \\
\hline CR & $\begin{array}{c}-2.276779 * * \\
(1.085654)\end{array}$ & $\begin{array}{c}-0.5791212 \\
(0.670997)\end{array}$ & $\begin{array}{c}-0.069276^{* * *} \\
(0.026092)\end{array}$ & $\begin{array}{c}0.440904 \\
(0.659815)\end{array}$ \\
\hline Constant & $\begin{array}{c}42.582170 * * * \\
(9.817857)\end{array}$ & $\begin{array}{c}-2.591660 * * \\
(1.067999)\end{array}$ & $\begin{array}{l}-0.160563 \\
(0.239092)\end{array}$ & $\begin{array}{c}43.504130 * * * \\
(5.966878)\end{array}$ \\
\hline $\mathrm{R}^{2}:$ overall & 0.4526 & 0.9081 & 0.9394 & 0.9295 \\
\hline $\mathrm{F}$ & $25.64^{* * *}$ & $306.40^{* * *}$ & $542.48 * * *$ & $408.52 * * *$ \\
\hline Hausman test $\mathrm{chi}^{2}$ & $\mathrm{RE}$ & RE & $\mathrm{RE}$ & RE \\
\hline
\end{tabular}

Note: Standard errors are included in parentheses. ${ }^{*},{ }^{* *},{ }^{* * *}$ represent $10 \%, 5 \%, 1 \%$ statistical level, respectively $\mathrm{RE}$ denotes fixed-effects and random-effects estimates.

\subsection{The Nonlinear Effects of Regional Integration on Land Revenue Dependence}

Based on the threshold detection method proposed by Hansen [52], this study conducted the threshold effect test to determine the number of thresholds. The bootstrap self-sampling method and the software Stata 13.0 were adopted. Each sample was repeatedly measured 500 times, and the results were shown in Table 4.

Table 4. Overall threshold effect test in UAMRYR.

\begin{tabular}{ccccc}
\hline $\begin{array}{c}\text { Threshold } \\
\text { Variables }\end{array}$ & $\begin{array}{c}\text { Threshold } \\
\text { Effects }\end{array}$ & F-Statistics & $p$-Values & $\begin{array}{c}\text { Threshold } \\
\text { Values }\end{array}$ \\
\hline RI & Single & $9.77^{*}$ & 0.0650 & 5.4381 \\
\hline RI-lag & Double & 2.03 & 0.4825 & $(5.6795,6.2888)$ \\
\hline & Single & $16.66^{* * *}$ & 0.0000 & -0.3400 \\
\hline & Double & $12.54^{*}$ & 0.0625 & $(-0.3157,0.4736)$ \\
\hline
\end{tabular}

Note: ${ }^{* * *}, * * *$ represent $10 \%, 5 \%, 1 \%$ statistical level, respectively.

As can be seen from Table 4, when RI is used as the threshold variable, the value of F-statistics under the hypothesis of the single threshold is 9.77 , and it passes the significance level test with a $90 \%$ confidence degree. The double threshold effect is not significant. When RI-lag is used as the threshold variable, the value of F-statistics under the hypothesis of the single threshold is 16.66 , and it passes the test at the significance level of $1 \%$. The threshold effect of the double threshold is also not significant. This verifies the inverted U-shaped relationship proposed in Hypothesis 3. In contrast, the significance level of RI-lag is much higher than that of RI, which meets the rigorous requirements. Therefore, RI-lag is selected as the threshold variable for further regression analysis, as Table 5 shows.

From the regression results of the UAMRYR, the coefficient of the impact of RI on the land revenue dependence in the base period is 0.264872, and it has passed the test of significance at a $10 \%$ level. After the first and second lag, however, the estimated coefficients were -1.361557 and -1.622170 , respectively, and passed the test of significance at $1 \%$ level and $5 \%$, respectively. This indicates that with the extension of lag periods, RI can effectively alleviate the land revenue dependence [14], and shows the characteristics of 
diminishing marginal efficiency [25]. In the Chang-Zhu-Tan city-clusters, as the lag period increases, the influence of RI on the land revenue dependence also shows the characteristics of first promoting and then alleviating. The impact of RI on the land revenue dependence in the Wuhan city-clusters exhibited an N-shaped trend. Specifically, the estimated value of RI in the current period is 0.264885 , and it has passed the test of the $10 \%$ significance level. The estimated value of RI-lag (1) is -3.361558 , which has passed the test of the $5 \%$ significance level. The estimated value of RI-lag (2) is 1.122165, which has passed the test of the $1 \%$ significance level. In the Poyang Lake city-clusters, both the base period and the lag period of RI showed the same characteristics as other samples. However, the coefficient estimates for RI-lag (1) did not pass the statistical test. In summary, at three sub-urban agglomerations levels, our results reveal that regional integration may first encourage and then suppress land finance dependence when RI-lag was defined as a threshold variable.

Table 5. The results of threshold regression with RI-lag as threshold variable.

\begin{tabular}{|c|c|c|c|c|}
\hline Variable & Model IX & Model X & Model XI & Model XII \\
\hline Region & UAMRYR & $\begin{array}{c}\text { Wuhan } \\
\text { City-Clusters }\end{array}$ & $\begin{array}{l}\text { Chang-Zhu-Tan } \\
\text { City-Clusters }\end{array}$ & $\begin{array}{l}\text { Poyang Lake } \\
\text { City-Clusters }\end{array}$ \\
\hline ED & $\begin{array}{c}0.793923 \\
(1.141309)\end{array}$ & $\begin{array}{c}-1.386588 * \\
(0.807298)\end{array}$ & $\begin{array}{l}-0.799977 \\
(0.989237)\end{array}$ & $\begin{array}{c}-1.319219 * \\
(0.766848)\end{array}$ \\
\hline RK & $\begin{array}{c}-0.020605^{* * *} \\
(0.004477)\end{array}$ & $\begin{array}{c}-0.000641^{* * *} \\
(0.000208)\end{array}$ & $\begin{array}{c}-0.00000624 \\
(0.000596)\end{array}$ & $\begin{array}{l}-0.000564 \\
(0.001236)\end{array}$ \\
\hline TR & $\begin{array}{c}4.570327^{* * *} \\
(1.432498)\end{array}$ & $\begin{array}{c}-0.123771 * * * \\
(0.0003874)\end{array}$ & $\begin{array}{c}0.0089341 \\
(0.2448303)\end{array}$ & $\begin{array}{c}-0.1777888 * \\
(0.9272095)\end{array}$ \\
\hline $\mathrm{TE}$ & $\begin{array}{c}-0.134056^{* * *} \\
(0.028992)\end{array}$ & $\begin{array}{c}0.004308^{* * *} \\
(0.001744)\end{array}$ & $\begin{array}{c}-0.104596^{* * *} \\
(0.007139)\end{array}$ & $\begin{array}{l}-0.007239 \\
(0.005112)\end{array}$ \\
\hline OW & $\begin{array}{c}-12.734000 * * * \\
(2.797978)\end{array}$ & $\begin{array}{c}-0.3849605^{* * *} \\
(0.187343)\end{array}$ & $\begin{array}{c}-0.6044255 \text { * } \\
(0.323752)\end{array}$ & $\begin{array}{l}-0.675320 \\
(0.511030)\end{array}$ \\
\hline FI & $\begin{array}{l}23.136980 * * \\
(11.935010)\end{array}$ & $\begin{array}{c}16.387620 \\
(10.623190)\end{array}$ & $\begin{array}{c}1.055100^{* * *} \\
(0.247000)\end{array}$ & $\begin{array}{l}1.851900 * \\
(1.100200)\end{array}$ \\
\hline TA & $\begin{array}{c}9.614730 \\
(8.281704)\end{array}$ & $\begin{array}{c}1.731500 \\
(.1 .624746)\end{array}$ & $\begin{array}{l}-0.258663 \\
(1.687094)\end{array}$ & $\begin{array}{c}0.639031 \\
(1.648168)\end{array}$ \\
\hline FDI & $\begin{array}{c}20.158880 \\
(68.258160)\end{array}$ & $\begin{array}{c}-32.802030 * * * \\
(10.819120)\end{array}$ & $\begin{array}{c}-11.996350 * \\
(6.036154)\end{array}$ & $\begin{array}{c}-13.027330 \text { ** } \\
(7.165635)\end{array}$ \\
\hline $\mathrm{CR}$ & $\begin{array}{c}-0.695239 * * \\
(0.272670)\end{array}$ & $\begin{array}{l}-0.137486 \\
(0.088318)\end{array}$ & $\begin{array}{l}-0.102078 \\
(0.093993)\end{array}$ & $\begin{array}{c}-0.097949 \text { *** } \\
(0.003779)\end{array}$ \\
\hline RI-lag (0) & $\begin{array}{l}0.264872 * \\
(0.140616)\end{array}$ & $\begin{array}{l}0.264885 * \\
(0.140664)\end{array}$ & $\begin{array}{l}2.602484 * \\
(1.484073)\end{array}$ & $\begin{array}{l}2.643476^{* *} \\
(1.064822)\end{array}$ \\
\hline RI-lag (1) & $\begin{array}{c}-1.361557^{* *} \\
(0.279424)\end{array}$ & $\begin{array}{c}-3.361558^{* *} \\
(1.279443)\end{array}$ & $\begin{array}{l}-2.164277^{*} \\
(1.275964)\end{array}$ & $\begin{array}{l}-1.439879 \\
(2.196934)\end{array}$ \\
\hline RI-lag (2) & $\begin{array}{c}-1.622170 \text { *** } \\
(0.136594)\end{array}$ & $\begin{array}{c}1.122165^{* * *} \\
(0.136522)\end{array}$ & & \\
\hline Constant & $\begin{array}{c}-0.180198 * * \\
(0.089708)\end{array}$ & $\begin{array}{l}5.327969 * \\
(3.097914)\end{array}$ & $\begin{array}{c}1.978498 \\
(2.134493)\end{array}$ & $\begin{array}{c}3.739557 \\
(4.857711)\end{array}$ \\
\hline $\mathrm{R}^{2}$ : overall & 0.1850 & 0.0119 & 0.1576 & 0.0954 \\
\hline $\mathrm{F}$ & $18.39^{* * *}$ & $2.54^{* *}$ & $1.98^{* *}$ & 1.70 \\
\hline sman test chi ${ }^{2}$ & $\mathrm{FE}$ & $\mathrm{FE}$ & $\mathrm{FE}$ & $\mathrm{FE}$ \\
\hline
\end{tabular}

Note: Standard errors are included in parentheses. ${ }^{*},{ }^{* *},{ }^{* * *}$ represent $10 \%, 5 \%, 1 \%$ statistical level respectively, $\mathrm{FE}$ denotes fixed-effects and random-effects estimates.

\subsection{Robustness Test}

To improve the credibility of the results, the method replacing the explained variable was adopted to the robustness test. Combing and referring to the existing literature $[53,54]$, 
this study replaces the proxy variable of land finance with per unit land transfer price through bidding, auction, and listing (PULTP). Compared with the variable "reliance on land finance", the coefficient of variable "PULTP" is much higher and passed the test at the $10 \%$ level of significance (Model 1 in Table 6). The influence of each control variable did not change significantly. This study further explores the nonlinear impact of regional integration on land finance, using PULYP as a dependent variable (Model 2 in Table 6). Regional integration has a significant single threshold effect on land finance. When the level of regional integration is less than the threshold value of 5.4381, the impact is significantly positive. When the level of integration crosses the threshold value, the impact of regional integration on land finance changes from positive to negative. This result also provides more convincing empirical support for Hypothesis 3. In summary, the estimation results in this study are credible and robust.

Table 6. Results of the robustness test.

\begin{tabular}{|c|c|c|}
\hline Dependent Variables & Model 1 & Model 2 \\
\hline & RI Index & PULTP \\
\hline PULTP & $\begin{array}{l}0.0919163 * \\
(0.1038092)\end{array}$ & - \\
\hline RI-lag (0) & - & $\begin{array}{c}0.1447887 * \\
(0807169)\end{array}$ \\
\hline RI-lag (1) & - & $\begin{array}{c}-0.5371786 \text { ** } \\
(0.2401264)\end{array}$ \\
\hline RI-lag (2) & - & $\begin{array}{c}-0.2056869 \\
(0.1371188)\end{array}$ \\
\hline Control & Yes & Yes \\
\hline City-specific effects & Yes & Yes \\
\hline Year dummies & Yes & Yes \\
\hline Constant & $\begin{array}{c}0.000000477 \\
(0.022047)\end{array}$ & $\begin{array}{c}-0.1418376 * \\
(0.0819649)\end{array}$ \\
\hline $\mathrm{R}^{2}$ : overall & 0.9050 & 0.1518 \\
\hline $\mathrm{F}$ & $152.7^{* * *}$ & $33.55 * * *$ \\
\hline Hausman test chi $^{2}$ & FE & $\mathrm{FE}$ \\
\hline
\end{tabular}

\section{Conclusions and Policy Implications}

\subsection{Conclusions}

Land is closely and inseparably related to regional economic and social development [55]. Since the reform of China's tax-sharing system in 1994, the size of China's land finance has expanded rapidly $[5,11]$. Land finance serves as a supplement to local fiscal revenue to maintain the basic functions of local governments [1]. Besides, land finance provides funds for local governments to further enhance the level of urbanization, improve urban public facilities, and promote economic development [8]. Regional integration is a high-level manifestation of China's new urbanization strategy. Its formation and development have a strong connection with the local governments' behavior for land finance.

This study conceptually and empirically investigates the relationship between land finance and regional integration. We used panel data of the UAMRYR from 2003 to 2016 to explore whether land finance promotes regional integration or promotes polarization. And in turn, whether regional integration increases or hinders land finance. Our empirical results verified that land finance has a mixed and complex effect on regional integration. This study indicated that the size of land finance promotes $0.000040 \%$ for regional integration at 
a 5\% statistical level. This result preliminarily was consistent with the expected outcome of this paper that Hypothesis 1 assumes. Furthermore, we clarified and confirmed that a $1 \%$ increase in revenue of land conveyance also increases regional integration by $0.000021 \%$ for Wuhan city-clusters, $0.000089 \%$ for Chang-Zhu-Tan city-clusters, and $0.000018 \%$ for Poyang Lake city-clusters. However, the increase in the degree of reliance on land finance decreases the level of regional integration. In turn, there is a significant threshold influence of regional integration on land finance reliance. A significant negative sign was spotted between regional integration and land finance reliance. This outcome indicated the correctness of our theoretical model. When the value of RI-lag crossed the first threshold, a 1\% increase in RI caused a $-1.361557 \%$ decrease in land finance reliance. At the later stage, this negative impact will become bigger and bigger.

\subsection{Policy Implications}

The policy implications of our study need to be discussed for the reform of land finance policies and the implementation of city development strategies.

On the one hand, as a coin has two sides, land finance has positive and negative impacts on regional integration. What we should focus on is the net effect of the size of land finance and reliance on land finance. The quite real question lay on how to balance its positive and negative effects. Therefore, an urgent task is to recognize how to capture land value. Specifically, a more specific sprawl policy and a more well-performed approach would be more helpful in using land finance to sustain coordinated integration development [56]. Moreover, it is significant to develop low-hill and gently-sloped land to meet the demand of land finance and rural revitalization strategy. These measures enable local governments to hold current rates of land development, then consolidate and expand land funding sources [57]. Setting a more proportion of revenue from land conveyance being allocated to local government would broaden the positive impact of land finance on regional integration.

On the other hand, this study has also clarified the changeable land finance reliance in different historical stages of regional integration. Based on our empirical results, the UAMRYR should optimize the regional spatial linkage environment while actively constructing the watershed community. At the same time, smoothing the flow channels of production factors among different regions and improving the mechanism of regional industrial cooperation [58]. In this way, the process of regional integration has been accelerated, and the turning points in the inverted U-shaped curve would be much earlier. Another imperative is to rationally formulate the development strategy for a particular urban agglomeration based on the synergy between land finance and regional integration. For example, the top priority of Wuhan city-clusters is to achieve the connotative upgrading of regional economic integration through accelerating economic transformation, deepening market-oriented reform, upgrading infrastructure construction, and innovating the public service system.

\subsection{Limitations and Further Prospects}

Admittedly, this study has several limitations. Firstly, due to limited data availability, some expected indicators (infrastructure connectivity, trade barriers, and ecological joint governance, etc.) are not considered when measuring regional integration. In the context of "green growth" and sustainable development, increasing attention has been paid to highquality integration. Future research can follow this trend and measure the level of regional integration more accurately. Secondly, the evaluation indicators of land finance should be diversified. Different types of land transactions should be applied for in-depth analyses, due to the increasing scarcity of land resources, the slowdown of urban expansions, and the well-established legal and institutional systems. Finally, the effects of institutional factors on land finance are also not considered because of the limited data. Variables like rural development [59], socioeconomic issues [60], and microfinance factors [61] would be used 
to investigate the relationship between land finance and regional integration. When more relevant data becomes available, efforts can be made to quantify.

Author Contributions: Conceptualization, X.L. and M.B.; methodology, B.K.; software, B.K. and D.C.; validation, X.L. and M.B.; formal analysis, D.C.; investigation, B.K.; resources, D.C.; data curation, D.C.; writing—original draft preparation, X.L., M.B. and B.K.; writing-review and editing, B.K.; visualization, D.C.; supervision, B.K. and D.C.; project administration, X.L.; funding acquisition, X.L., B.K. and D.C. All authors have read and agreed to the published version of the manuscript.

Funding: This research was funded by the National Natural Science Foundation of China (Grant No. 41901256, 42101307), Humanity and Social Science Research Funds of Ministry of Education (MOE) of China (Grant No. 21YJC790006), Independent Science and Technology Innovation Fund of Huazhong Agricultural University, PR China (Grant No. 2662020GGQD001), Self-determined Research Funds of CCNU from the Colleges' Basic Research and Operation of MOE of China (CCNU20QN036, CCNU19TD004).

Institutional Review Board Statement: Not applicable.

Informed Consent Statement: Not applicable.

Data Availability Statement: All the data were from the China City Statistical Yearbook (Available online: https://data.cnki.net/yearbook/Single/N2021050059, accessed on 20 August 2021), and China Land and Resources Statistical Yearbook (Available online: https: / / data.cnki.net/yearbook/ Single/N2020030130, accessed on 20 August 2021).

Conflicts of Interest: The authors declare no conflict of interest.

\section{References}

1. Cao, G.Z.; Feng, C.C.; Tao, R. Local land finance in China's urban expansion: Challenges and solutions. China World Econ. 2008, 16, 19-30. [CrossRef]

2. Palmer, I.; Berrisford, S. Urban Infrastructure in Sub-Saharan Africa-Harnessing Land Values, Housing and Transport: Final Report on Land-Based Financing for Urban Infrastructure in Sub-Saharan African Cities. Available online: https://assets. publishing.service.gov.uk/media/57a08978ed915d622c000227/61319C_Full-DFID-Report_Web.1.1.pdf (accessed on 31 July 2015).

3. Peterson, G.E. Unlocking Land Values to Finance Urban Infrastructure; World Bank Publications: Washington, DC, USA, 2009.

4. Anderson, J.E. Collecting land value through public land leasing. In Value Capture and Land Policies; Ingram, G.K.I., Hong, Y.H., Eds.; Lincoln Institute of Land Policy: Bolton, MA, USA, 2012.

5. Wu, Q.; Li, Y.L.; Yan, S.Q. The incentives of China's urban land finance. Land Use Policy 2015, 42, 432-442.

6. Shen, C.L.; Jin, J.; Zou, H.F. Fiscal decentralization in China: History, impact, challenges and next steps. Ann. Econ. Financ. 2012, 13, 1-51.

7. Liu, Z. Land-based finance and property tax in China. Area Dev. Policy 2019, 4, 367-381. [CrossRef]

8. Huang, D.X.; Chan, R.C.K. On 'land finance' in urban China: Theory and practice. Habitat Int. 2018, 75, 96-104. [CrossRef]

9. $\mathrm{Fu}, \mathrm{Q}$. When fiscal recentralisation meets urban reforms: Prefectural land finance and its association with access to housing in urban China. Urban Stud. 2015, 52, 1791-1809. [CrossRef]

10. Geng, B.; Zhang, X.L.; Liang, Y.; Bao, H.J.; Skitmore, M. Sustainable land financing in a new urbanization context: Theoretical connotations, empirical tests and policy recommendations. Resour. Conserv. Recycl. 2018, 128, 336-344. [CrossRef]

11. Mo, J.W. Land financing and economic growth: Evidence from Chinese counties. China Econ. Rev. 2018, 50, 218-239. [CrossRef]

12. Zhang, X.P.; Chen, D.L.; Lu, X.H.; Tang, Y.F.; Jiang, B. Interaction between land financing strategy and the implementation deviation of local governments' cultivated land protection policy in China. Land 2021, 10, 803. [CrossRef]

13. Qu, Y.C.M.; Zhang, Z.Q.; Feng, Y.C. Effects of land finance on resource misallocation in Chinese cities during 2003-2017: A dynamic panel econometric analysis. Discrete Dyn. Nat. Soc. 2020, 2020, 2639024. [CrossRef]

14. Lu, X.H.; Chen, D.L.; Kuang, B. Is regional integration exacerbating the land financial dependence?-A case study of the Yangtze River Economic Belt. J. Huazhong Agric. Univ. (Soc. Sci. Ed.) 2019, 146-154, 169-170. (In Chinese)

15. Zhong, T.Y.; Zhang, X.L.; Huang, X.J.; Liu, F. Blessing or curse? Impact of land finance on rural public infrastructure development. Land Use Policy 2019, 85, 130-141. [CrossRef]

16. Rithmire, M.E. Land institutions and Chinese political economy: Institutional complementarities and macroeconomic management. Politics Soc. 2017, 45, 123-153. [CrossRef]

17. Cho, S.H.; Wu, J.J.; Boggess, W.G. Measuring interactions among urbanization, land use regulations, and public finance. Am. J. Agric. Econ. 2003, 85, 988-999. [CrossRef]

18. Peterson, G.E. Land Leasing and Land Sale as an Infrastructure-Financing Option, 2006. World Bank Policy Research Working Paper No. 4043. Available online: https: / / ssrn.com/abstract=940509 (accessed on 20 August 2021). 
19. Liu, T.; Cao, G.; Yan, Y.; Wang, R.Y. Urban land marketization in China: Central policy, local initiative, and market mechanism. Land Use Policy 2016, 57, 265-276. [CrossRef]

20. Hou, S.Y.; Song, L.R.; Wang, J.Q.; Ali, S. How land finance affects green economic growth in Chinese cities. Land 2021, 10, 819. [CrossRef]

21. Han, L.; Kung, J.K.S. Fiscal incentives and policy choices of local governments: Evidence from China. J. Dev. Econ. 2015, 116, 89-104. [CrossRef]

22. Guo, S.; Shi, Y.Y. Infrastructure investment in China: A model of local government choice under land financing. J. Asian Econ. 2018, 56, 24-35. [CrossRef]

23. Bertaud, A. Government intervention and urban land markets: The case of China. J. Archit. Plan. Res. 2012, 29, 335-346.

24. Xu, N.N. What gave rise to China's land finance? Land Use Policy 2019, 87, 104015. [CrossRef]

25. Lu, X.H.; Chen, D.L.; Kuang, B. Indicator system design and regional difference of urban land use efficiency under the background of regional integration. China Popul. Resour. Environ. 2018, 28, 102-110.

26. Besley, T.; Burgess, R. Land reform, poverty reduction, and growth: Evidence from India. Q. J. Econ. 2000, 115, 389-430. [CrossRef]

27. Dharmapuri, T.R.; Piyush, T. Land-based financing elements in infrastructure policy formulation: A case of India. Land 2021, 10, 133.

28. Gu, C. Study on urban agglomeration: Progress and prospects. Geogr. Res. 2011, 30, 771-783.

29. Ejones, F.; Agbola, F.W.; Mahmood, A. Regional integration and economic growth: New empirical evidence from the east African community. Int. Trade J. 2021, 35, 1-25. [CrossRef]

30. Bouvet, F. Regional integration and income inequality: A synthetic counterfactual analysis of the European Monetary Union. Oxford Rev. Econ. Pol. 2021, 37, 172-200. [CrossRef]

31. You, S.; Chen, X. Regional integration degree and its effect on a city's green growth in the Yangtze River Delta: Research based on a single-city regional integration index. Clean Technol. Environ. Policy 2021, 23, 1837-1849. [CrossRef]

32. Lin, G.C.S. Regional integration in south China: Processes and consequences in a local economy of the Pearl River Delta. Asian Perspect. 2021, 25, 93-125. [CrossRef]

33. Ludé, D.A.; Thérèse, E.Z. Governance, infrastructure and regional integration: The case of CEMAC. Mod. Econ. 2020, 11, 1950-1965. [CrossRef]

34. Xie, R.; Yao, S.L.; Han, F.; Fang, J.Y. Land Finance, producer services agglomeration, and green total factor productivity. Int. Reg. Sci. Rev. 2019, 42, 550-579. [CrossRef]

35. Wang, W.; Ye, F.Z. The political economy of land finance in China. Public Budg. Financ. 2016, 36, 91-110. [CrossRef]

36. Wang, R.; Hou, J. Land finance, land attracting investment and housing price fluctuations in China. Inter. Rev. Econ. Financ. 2021, 72, 690-699. [CrossRef]

37. Jin, C.H.; Choi, M.J. The causal structure of land finance, commercial housing, and social housing in China. Int. J. Urban Sci. 2019, 23, 1-14. [CrossRef]

38. Wang, Z.F.; Cao, C.Y.; Chen, J.H.; Wang, H. Does land finance contraction accelerate urban shrinkage? A study based on 84 key cities in China. J. Urban Plan. Dev. 2020, 146, 04020038. [CrossRef]

39. Vyas, I.; Vyas, H.N.; Mishra, A.K. Land-based financing of cities in India: A study of Bengaluru and Hyderabad and directions for reforms. J. Public Aff. 2020, e2386, in press. [CrossRef]

40. Wang, P.; Shao, Z.N.; Wang, J. The impact of land finance on urban land use efficiency: A panel threshold model for Chinese provinces. Growth Chang. 2021, 52, 310-331. [CrossRef]

41. Ma, S.F.; Zhao, Y.B.; Tan, X.H. Exploring smart growth boundaries of urban agglomeration with land use spatial optimization: A case study of Changsha-Zhuzhou-Xiangtan City Group, China. Chin. Geogr. Sci. 2020, 30, 665-676. [CrossRef]

42. Wang, J.; Skidmore, M.; Wu, Q.; Wang, S. The impact of a tax cut reform on land finance revenue: Constrained by the binding target of construction land. J. Urban Aff. 2020. [CrossRef]

43. Parsley, D.C.; Wei, S.J. A Prism into the PPP Puzzles: The Micro Foundations of Big Mac Real Exchange Rates; Working Paper No. 10074; National Bureau of Economic Research: Cambridge, MA, USA, 2003.

44. Engel, C.; Rogers, J.H. Regional patterns in the law of one price: The roles of geography versus currencies. In The Regionalization of the World Economy; Frankel, J.A., Ed.; University of Chicago Press: Chicago, IL, USA, 1998; pp. 153-188.

45. Alfaihani, S.; Badunenko, O.; Jaffry, S. Market size and market structure in banking. J. Int. Financ. Mark. I. 2021, 72, 101342. [CrossRef]

46. Chen, Z.H.; Li, Y.; Wang, P. Transportation accessibility and regional growth in the Greater Bay Area of China. Transport. Res. D Transp. Environ. 2020, 86, 102453. [CrossRef]

47. Wang, X.; Manry, D.; Rosa, G. Ownership structure, economic fluctuation, and capital structure: Evidence from China. Int. J. Financ. Econ. 2019, 24, 841-854. [CrossRef]

48. Ouyang, A.Y.; Li, R. Fiscal decentralization and the default risk of Chinese local government debts. Contemp. Econ. Policy 2021, 39, 641-667. [CrossRef]

49. Leibovici, F. International trade openness and monetary policy: Evidence from cross-country data. Fed. Reserve. Bank St. 2019, 101, 93-113. [CrossRef]

50. Gabriel, C.R. The employment effects of credit market disruptions: Firm-level evidence from the 2008-9 financial crisis. Q. J. Econ. 2013, 129, 1-59. 
51. Francois, P. Economic space: Theory and applications. Q. J. Econ. 1950, 64, 89-104.

52. Hansen, B.E. Sample Splitting and Threshold Estimation. Econometrica 2000, 68, 575-604. [CrossRef]

53. Wang, D.; Ren, C.R.; Zhou, T. Understanding the impact of land finance on industrial structure change in China: Insights from a spatial econometric analysis. Land Use Policy 2021, 103, 105323. [CrossRef]

54. Lu, J.; Li, B.; Li, H. The influence of land finance and public service supply on peri-urbanization: Evidence from the counties in China. Habitat Int. 2019, 92, 102039. [CrossRef]

55. Kuang, B.; Lu, X.H.; Zhou, M.; Chen, D.L. Provincial cultivated land use efficiency in China: Empirical analysis based on the SBM-DEA model with carbon emissions considered. Technol. Forecast. Soc. 2020, 151, 119874. [CrossRef]

56. Yang, T.; Jin, Y.; Yan, L.; Pei, P. Aspirations and realities of polycentric development: Insights from multi-source data into the emerging urban form of Shanghai. Environ. Plan. B Urban Anal. City Sci. 2019, 46, 1264-1280. [CrossRef]

57. Tao, R.; Su, F.B.; Liu, M.X.; Cao, G.Z. Land leasing and local public finance in China's regional development: Evidence from prefecture-level cities. Urban Stud. 2010, 47, 2217-2236.

58. IMF. External Relations Dept. From the Editor: Next Phase of the Crisis. Financ. Dev. 2008, 45, 59. [CrossRef]

59. Gatto, A.; Polselli, N.; Bloom, G. Empowering gender equality through rural development: Rural markets and micro-Finance in Kyrgyzstan. In L'Europa E La Comunità Internazionale Difronte Alle Sfide Dello Sviluppo; Giannini: Naples, Italy, 2016 ; pp. 65-89.

60. Hu, F.Z.Y.; Qian, J.W. Land-based finance, fiscal autonomy and land supply for affordable housing in urban China: A prefecturelevel analysis. Land Use Policy 2017, 69, 454-460. [CrossRef]

61. Gatto, A. Historical roots of microcredit and usury: The role of monti di Pietà in Italy and in the Kingdom of Naples in XV-XX centuries. J. Int. Dev. 2018, 30, 911-914. [CrossRef] 